\title{
Kondisi Terumbu Karang di Kawasan Taman Nasional Laut Kepulauan Seribu DKI Jakarta
}

\author{
The Condition of Coral Reefs in Kepulauan Seribu Marine National Park DKI Jakarta
}

Drajad Sarwo Seto, Djumanto*, dan Namastra Probosunu

Jurusan Perikanan, Fakultas Pertanian, Universitas Gadjah Mada

Jln. Flora, Bulaksumur, Yogyakarta 55281

E-mail:lely4192@yahoo.com_*Penulis untuk korespondensi

\begin{abstract}
The objective of this research was to determine the condition of coral reefs, namely the percentage of coral covered, species distribution, community structure of coral, and the environmental conditions surround the core zone, protection zone, tourism zone, and residential zone in Kepulauan Seribu Marine National Park DKI Jakarta. The research was conducted from 8 to 16 May, 2013. The data was collected from four zones and each zone was set up into two stations as a point observation, at the depth of 7-9 meters. The percentage of coral coverring was calculated by line intercept transect method, coral genera was counted and identified using the belt transect method. Coral data was analyzed qualitatively based on ecological index. The results showed that the coral covering was range from 7.25 to $68.93 \%$ as categorized from bad to good condition. The number of coral was found approximately of 5.523 colonies that consisted of $\mathbf{4 5}$ genera and $\mathbf{1 6}$ families. The most abundance of coral was Porites and Montipora with percentage of $19.7 \%$ and $16.69 \%$, respectively. Coral diversity index was ranged from 1.61 to 3.07 as indicated of low to high. Uniformity index was ranged from 0.44 to 0.68 , which was the community in stressful to labile situation. Dominance index (D) was ranged from 0.06 to 0.32 showing that coral dominance was absence.
\end{abstract}

Keywords: Coral reef, cover, diversity, Kepulauan Seribu

Abstrak

Penelitian ini bertujuan mengetahui kondisi terumbu karang yang meliputi persentase tutupan, sebaran, struktur komunitas dan kondisi lingkungan di zona inti, perlindungan, pemanfaatan wisata, dan pemukiman di kawasan Taman Nasional Laut Kepulauan Seribu DKI Jakarta. Penelitian dilaksanakan dari tanggal 8 sampai 16 Mei 2013. Pengambilan data berada pada empat zona pengelolaan dan setiap zona ditetapkan sebanyak dua stasiun pengamatan pada kedalaman 7-9 meter. Persentase tutupan karang dihitung dengan metode Line Intercept Transect, genera karang dihitung dan diidentifikasi menggunakan metode Belt Transect. Data jenis karang yang diperoleh dianalisis kualitatif berdasarkan indeks ekologis. Hasil penelitian diperoleh persentase tutupan karang berada pada kisaran 7,25-68,93\% yang dikategorikan kondisinya buruk hingga baik. Jumlah karang dari seluruh stasiun penelitian sebanyak 5.523 koloni yang terdiri dari 45 genera dan 16 famili. Genus karang yang paling sering dijumpai adalah Porites dan Montipora dengan persentase kelimpahannya masing-masing $\mathbf{1 9 , 7 \%}$ dan 16,69\%. Nilai indeks keanekaragaman (H') karang berkisar antara 1,61-3,07 yang tergolong rendah hingga tinggi. Indeks keseragaman berkisar 0,44-0,68 yang berarti komunitas dalam keadaan tertekan hingga labil. Nilai indeks dominansi (D) berkisar 0,06-0,32 yang menunjukkan dominansi karang tertentu tergolong rendah.

Kata kunci: Tutupan, terumbu karang, keragaman, Kepulauan Seribu. 


\section{Pendahuluan}

Indonesia sebagai negara kepulauan memiliki ekosistem terumbu karang yang sangat luas. Ekosistem terumbu karang sangat penting, karena menjadi tempat hidup bagi berbagai jenis ikan dan biota laut lainya. Ekosistem terumbu karang yang sehat dapat menyediakan sumber bahan pangan yang melimpah dan jasa lingkungan bagi nelayan dan masyarakat. Namun, terumbu karang di Indonesia mengalami tekanan yang besar akibat aktivitas manusia. Jumlah penduduk yang besar dan semakin meningkat dari tahun ke tahun membutuhkan berbagai sumber daya untuk memenuhi kebutuhan hidup yang berupa pangan, sandang, dan papan. Kegiatan pemanfaatan sumber daya alam tersebut seringkali dilakukan dengan tidak mempertimbangkan kelestariannya. Penangkapan ikan secara berlebihan, cara penangkapan yang tidak ramah lingkungan, penambangan terumbu karang, dan pencemaran air mengakibatkan kerusakan pada ekosistem perairan khususnya terumbu karang.

Karang adalah binatang dari filum Cnidaria kelas Anthozoa, ordo Scelerectinia. Terumbu karang merupakan endapan masif padat kalsium karbonat $\left(\mathrm{CaCO}_{3}\right)$ yang dihasilkan oleh hewan karang dengan sedikit tambahan dari alga berkapur (Calcareous algae) dan organisme-organisme lain yang mensekresikan kalsium karbonat. Pembentuk karang utama pada ekosistem terumbu karang merupakan hewan dari ordo Scelerectinia (Veron, 1993). Hewan karang merupakan polip yang mempunyai bentuk tubuh seperti tabung dengan mulut yang terletak di bagian atas dan dikelilingi oleh tentakel (Sorokin, 1993). Setiap individu polip karang akan berkembang menjadi beberapa individu yang disebut koloni (Nybakken, 1982).

Hewan karang dibedakan menjadi dua kelompok yaitu karang hermatipik dan ahermatipik. Karang hermatipik adalah karang yang menghasilkan terumbu dan penyebarannya hanya ditemukan di daerah tropis, sedangkan karang ahermatipik tidak menghasilkan terumbu dan merupakan kelompok yang tersebar luas di seluruh dunia. Pada karang hermatipik terdapat simbiosis mutualisme antara karang dengan zooxanthella sejenis alga uniseluler yang terdapat pada jaringan-jaringan polip hewan karang dan dapat melakukan proses fotosintesis.

Sebaran karang tergantung kondisi fisikkimia perairan yang terdiri dari cahaya, suhu, salinitas, arus, dan kejernihan. Cahaya merupakan faktor yang penting bagi kehidupan terumbu karang. Kebanyakan terumbu karang tumbuh pada kedalaman 25 meter atau kurang karena pada kedalaman tersebut cahaya matahari dapat menembus hingga dasar, sehingga dapat dimanfaatkan oleh zooxanthella untuk proses fotosintesis. Terumbu karang berkembang optimal di perairan dengan rata-rata suhu $23^{\circ}-25^{\circ} \mathrm{C}$ dan salinitas rata-rata $32-35 \%$. Arus berfungsi untuk membersihkan polip dari kotoran atau sedimentasi yang mengganggu penyerapan cahaya matahari. Arus juga berfungsi membawa oksigen dan plankton untuk hewan karang (Nybakken, 1992).

Taman Nasional Laut Kepulauan Seribu adalah kawasan perlindungan dan pelestarian alam yang terletak di utara Jakarta, Kabupaten Administratif Kepulauan Seribu, DKI Jakarta. Menurut SK. Dirjen Perlindungan Hutan dan Konservasi Alam Nomor 6186/Kpts-II/2002 Tanggal 10 Juni 2002, pengelolaan Taman Nasional Laut Kepulauan Seribu dilakukan oleh Balai Taman Nasional Kepulauan Seribu. Kawasan ini memiliki keanekaragaman jenis hayati yang tinggi dan merupakan ekosistem perairan laut dangkal yang tersusun atas ekosistem mangrove, lamun, dan terumbu karang.

Penelitian yang dilakukan oleh yayasan Terumbu Karang Indonesia (TERANGI) pada tahun 2005-2007 menyebutkan telah terjadi penurunan persentase tutupan karang di Kepulauan Seribu dari 34,2\% menjadi 31,7\%. Penurunan persentase tutupan karang hidup tersebut diakibatkan oleh kematian dan kerusakan karang. Taman Nasional Laut Kepulauan Seribu membuat sistem zonasi pengelolaan perairan untuk melindungi dari kerusakan terumbu karang. Penetapan zonasi didasarkan pada Keputusan Direktur Perlindungan Hutan dan Konservasi Alam Nomor : SK.05/VI-KK/2004 yang membagi kawasan TNLKpS ke dalam empat zona pengelolaan, yaitu zona inti, zona perlindungan, zona pemanfaatan wisata, dan zona pemukiman. 
Informasi mengenai kondisi terumbu karang pada setiap zonasi pengelolaan di Taman Nasional Laut Kepulauan Seribu masih terbatas. Oleh karena itu, perlu diadakan penelitian mengenai kondisi terumbu karang yang meliputi persentase tutupan karang keras, keanekaragaman, dan kondisi lingkunganya. Hasil penelitian ini dapat digunakan sebagai dasar untuk menyusun kebijakan pengelolaan konservasi sumberdaya perikanan.

\section{Metode Penelitian}

\section{Lokasi dan waktu sampling}

Penelitian ini dilakukan di kawasan Taman Nasional Laut Kepulauan Seribu (TNLKpS) dengan mengambil 8 stasiun pengamatan, masing-masing stasiun merupakan pulau atau gosong yang mewakili setiap zonasi pengelolaan yang ada di dalam kawasan TNLKpS (Tabel 1). Waktu sampling dilakukan pada tanggal 8-16 Mei 2013. Pengambilan data kondisi karang dilakukan di kedalaman 7-9 meter dengan memilih titik atau lokasi yang dapat mewakili kondisi perairan tersebut. Lokasi masing-masing stasiun pengamatan disajikan pada Gambar 1 .

\section{Tatalaksana penelitian}

Stasiun penelitian ditentukan dengan GPS sesuai dengan titik penelitian pada dua tahun sebelumnya. Pengambilan data menggunakan kapal motor, peralatan SCUBA, kamera bawah air, roll meter, alat tulis bawah air, secchi disk, termometer, refraktometer, floating drudge, dan stop watch. Data tutupan, jumlah koloni, dan jenis karang diamati dengan melakukan penyelaman. Data kualitas air diambil saat berada di atas kapal.

Penelitian dilakukan dengan menggunakan metode Line Intercept Transect (LIT) atau transek garis menyinggung dan metode Belt Transect atau transek sabuk, yang dikembangkan oleh Englishet dkk., (1994) dengan beberapa modifikasi. Metode LIT digunakan untuk melihat tutupan karang, sedangkan metode Belt Transect untuk mengamati jumlah koloni dan jenis karang digunakan.

Teknis pengambilan data dengan metode LIT dan Belt Transect yaitu seorang penyelam membentangkan meteran roll sepanjang $100 \mathrm{~m}$ pada kedalaman 7-10 m, kemudian dilakukan pengukuran tutupan karang dan komponen bentik lainnya sepanjang garis transek I (0-20m), II (25-45m), III (50-70m) dan IV (75-95m). Semua komponen biotik dan abiotik yang berada dibawah garis transek dicatat.

Metode Belt Transect mempunyai lebar satu meter ke kanan dan ke kiri, pencatatan jumlah koloni dan jenis karang dilakukan hampir sama ukurannya dengan metode LIT. Pada setiap stasiun penelitian dilakukan pengukuran parameter lingkungan perairan yang terdiri dari kecepatan arus, visibilitas, salinitas, suhu, dan derajat keasaman.

\section{Analisi data}

Analisis data tutupan karang dan komponen bentik dilakukan untuk persentase tutupan masing-masing kategori substrat yang dilalui transek (English dkk., 1994). Untuk menghitung persentase tutupan karang dapat dihitung dengan rumus:

Tutupan $(\%)=\frac{\text { Panjang total karang hidup }}{\text { Panjang total transek }} \times 100 \%$

Karang hidup diklasifikasikan berdasarkan persentase tutupannya, yaitu buruk $(0,0-24,9 \%)$, sedang $(25,0-49,9 \%)$, baik $(50,0-74,9 \%)$, dan sangat baik (75,0-100\%) (Gomez dan Yap 1988).

Data jumlah individu dan genus karang yang diperoleh dianalisis kuantitatif untuk melihat struktur komunitas karang yang meliputi keanekaragaman $\left(\mathrm{H}^{\prime}\right)$, keseragaman $(\mathrm{E})$, dan dominansi (C) yang dihitung menurut Odum (1998). Indeks keanekaragaman jenis dihitung dengan formula :

$$
H^{\prime}=-\sum \frac{n i}{N} \ln \frac{n i}{N}
$$

Keterangan :

$\mathrm{ni}=$ Jumlah individu genus ke- $\mathrm{i}$

$\mathrm{N}=$ Jumlah total individu seluruh genera

Indeks ini berdasarkan kaidah yang dikemukakan oleh Shannon-Wiener (Odum, 1998) untuk mengetahui keanekaragaman jenis biota perairan. Berdasarkan indeks ini dapat diduga kestabilan komunitas biota air. Indeks keanekaragaman Shannon Wiener berkisar 
antara $0-5$. Jika nilai indeks $<1$ atau mendekati 0 , diduga komunitas karang dalam kondisi tidak stabil. Jika nilai indeks 1-3 dapat diartikan bahwa tekanan komunitas karang pada tingkat sedang. Jika nilainya > 3 maka dapat diartikan komunitas karang pada tingkat stabil.

Indeks keseragaman jenis (E) dihitung dengan formula :

$$
E=\frac{H^{\prime}}{\operatorname{Ln} S}
$$

Keterangan :

$\mathrm{H}$ maks = indeks keanekaragaman maksimum

$\mathrm{S} \quad=$ jumlah jenis

Tabel 1. Lokasi pengamatan kondisi terumbu karang di Taman Nasional Kepulauan Seribu.

\begin{tabular}{lclcc}
\hline \hline \multirow{2}{*}{ Zonasi } & \multirow{2}{*}{ No. Stasiun } & \multirow{2}{*}{ Lokasi } & \multicolumn{2}{c}{ Koordinat } \\
\cline { 4 - 5 } & & & Lintang & \multicolumn{1}{c}{ Bujur } \\
\hline \hline Inti & 1 & Gosong Rengat & $5^{\circ} 27^{\prime} 55,68^{\prime \prime}$ LS & $106^{\circ} 26^{\prime} 14,10^{\prime \prime}$ BT \\
& 2 & P. Peteloran Timur & $5^{\circ} 27^{\prime} 12,20^{\prime \prime}$ LS & $106^{\circ} 33^{\prime} 53,22^{\prime \prime}$ BT \\
\hline Perlindungan & 3 & Gosong Sebaru & $5^{\circ} 29^{\prime} 39,24^{\prime \prime}$ LS & $106^{\circ} 33^{\prime} 22,14^{\prime \prime}$ BT \\
& 4 & P. Jagung & $5^{\circ} 28^{\prime} 47,58^{\prime \prime}$ LS & $106^{\circ} 31^{\prime} 17,28^{\prime \prime}$ BT \\
\hline Pemanfaatan & 5 & P. Jukung & $5^{\circ} 34^{\prime} 16,74^{\prime \prime}$ LS & $106^{\circ} 31^{\prime} 40,80^{\prime \prime}$ BT \\
& 6 & P. Sepa Besar & $5^{\circ} 34^{\prime} 32,40^{\prime \prime}$ LS & $106^{\circ} 34^{\prime} 46,50^{\prime \prime}$ BT \\
\hline Pemukiman & 7 & P. Opak Besar & $5^{\circ} 40^{\prime} 15,18^{\prime \prime}$ LS & $106^{\circ} 34^{\prime} 40,38^{\prime \prime}$ BT \\
& 8 & P. Panggang & $5^{\circ} 44^{\prime} 51,24^{\prime \prime}$ LS & $106^{\circ} 35^{\prime} 43,50^{\prime \prime}$ BT \\
\hline \hline
\end{tabular}

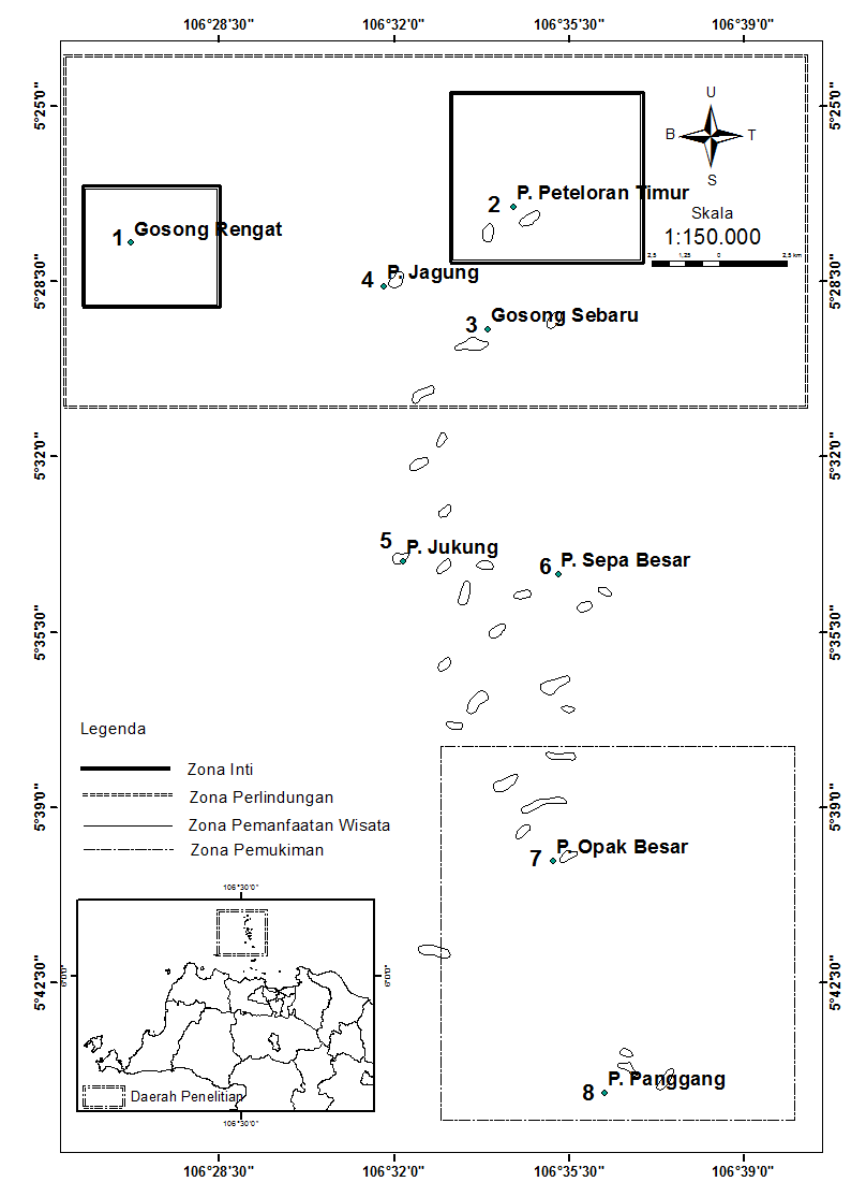

Gambar 1. Peta lokasi pengamatan terumbu karang di Taman Nasional Kepulauan Seribu. 
Nilai indeks keseragaman berkisar antara 0-1. Jika nilai E mendekati 0 maka keseragaman antar spesies rendah, sedangkan jika nilai $\mathrm{E}$ mendekati 1 maka keseragaman spesies tinggi. Indeks keseragaman dapat memberikan informasi kemerataan sebaran jenis karang.

Indeks dominansi (D) dihitung dengan rumus :

$$
\mathrm{D}=\sum\left(\frac{n i}{N}\right)^{2}
$$

Keterangan :
$\mathrm{N}=$ total cacah individu
$\mathrm{ni}=$ cacah individu dalam spesies ke-i

Nilai indeks dominansi berkisar antara 0-1. Apabila nilai indeks mendekati 1 maka ada kecenderungan suatu spesies mendominasi komunitas tersebut. Indeks ini digunakan untuk mengetahui ada tidaknya jenis yang mendominansi di perairan.

\section{Hasil dan Pembahasan}

Tutupan terumbu karang di kawasan Taman Nasional Laut Kepulauan Seribu mempunyai persentase yang bervariasi. Tutupan terumbu karang di perairan ini secara keseluruhan berkisar 7,25-68,93\% yang berarti ekosistem terumbu karang berada pada kondisi buruk hingga baik. Tutupan terumbu karang tiap stasiun pengamatan disajikan dalam Tabel 2.

Persentase penutupan karang keras pada zona inti yaitu stasiun 1 sebesar $26,61 \%$, stasiun 2 sebesar $29,31 \%$, zona perlindungan yaitu stasiun 3 sebesar $68,92 \%$, stasiun 4 sebesar $7,25 \%$, zona pemanfaatan wisata yaitu stasiun 5 sebesar $32,97 \%$, stasiun 6 sebesar $43,43 \%$, dan zona pemukiman stasiun 7 sebesar $61,65 \%$, stasiun 8 sebesar $55,57 \%$.

Sebaran tutupan karang keras dijumpai paling rendah di daerah utara yaitu daerah Pulau Jagung yang merupakan zona perlindungan dengan status buruk. Persebaran tutupan karang meningkat secara signifikan ke arah timur di daerah Pulau Gosong Sebaru yang merupakan zona perlindungan dengan status kondisi terumbu karangnya baik. Sebaran menurun sedikit ke bagian tengah. Terdapat dua stasiun yaitu Pulau Jukung dan Pulau Sepa Besar yang berada di daerah tengah dengan status kondisi terumbu karangnya adalah sedang. Persebaran tutupan karang keras kembali naik secara signifikan ke arah tenggara pada zona pemukiman.Terdapat dua stasiun penelitian pada zona pemukiman yaitu Pulau Opak Besar dan Pulau Panggang dengan status kondisi terumbu karangnya adalah baik.

Jumlah karang yang teramati di seluruh stasiun pengamatan adalah 5.523 koloni yang berasal dari 45 genera 16 famili. Jumlah individu karang dari masing-masing genus yang teramati berkisar antara 1-672 koloni. Beberapa genera karang di seluruh stasiun pengamatan memiliki kelimpahan yang besar. Genera karang dengan kelimpahan besar disajikan pada Gambar 2.

Beberapa karang memiliki kelimpahan yang besar di seluruh stasiun pengamatan. Persentase sepuluh genus karang dengan kelimpahan tertinggi yaitu dari genus Porites dengan kelimpahan sebesar 1088 koloni atau 19,70\%, Montipora dengan kelimpahan sebesar 922 koloni atau 16,69\%, Fungia sebanyak 404 koloni atau 7,31\%, Leptoseris sebanyak 359 koloni atau 6,50\%, Pavona sebanyak 337 koloni atau 6,10\%, Favia sebanyak 319 koloni atau $5,78 \%$, Seriatopora sebanyak 292 koloni atau 5,29\%, Acropora sebanyak 286 koloni atau 5,18\%, Goniastrea sebanyak 149 koloni atau 2,70\%, dan Galaxea sebanyak 142 koloni atau $2,57 \%$.

Data komunitas karang yang teramati di tiap-tiap stasiun pengamatan terdiri dari kekayaan genus yang ditemukan, indeks keanekaragaman (H'), indeks keseragaman (E), indeks dominansi (D) disajikan pada Tabel 3.

Indeks keanekaragaman karang di tiaptiap stasiun pengamatan berkisar antara 1,613,07 menandakan bahwa keanekaragamannya tergolong rendah sampai tinggi. Keanekaragaman karang paling rendah dengan nilai indeks 1,61 terdapat pada lokasi Pulau Jukung, sedangkan indeks keanekaragaman tertinggi terdapat pada lokasi Gosong Sebaru Besar dengan nilai indeks keanekaragaman 3,07. Indeks keseragaman karang (E) di tiap-tiap stasiun pengamatan berkisar antara 0,44-0,68, indeks keseragaman paling rendah terdapat di Pulau Sepa Besar sebesar 0,44, sedangkan indeks keseragaman paling tinggi terdapat di Pulau Jagung sebesar 0,68 . Indeks dominansi (D) berkisar antara 0,06-0,32. Nilai indeks dominansi tersebut 
tergolong dalam dominasi rendah. Nilai indeks dominansi tertinggi terdapat Pulau Jukung sedangkan terendah terdapat di Gosong Sebaru dan Pulau Opak Besar.

Kondisi lingkungan perairan mempunyai hubungan yang erat terhadap organisme atau biota yang hidup di dalamnya. Penurunan kualitas perairan dapat mengakibatkan perubahan komunitas ditandai dengan ledakan populasi tertentu. Parameter lingkungan selama kegiatan penelitian disajikan pada Tabel 4.

Tabel 2. Tutupan karang (\%) pada tiap stasiun pengamatan.

\begin{tabular}{lrrrrrrrr}
\hline \multirow{2}{*}{ Komponen } & \multicolumn{7}{c}{ Tutupan karang (\%) } \\
\cline { 2 - 8 } & ST 1 & ST 2 & ST 3 & ST 4 & ST 5 & ST 6 & ST 7 & ST 8 \\
\hline \hline Karang Hidup & 26,61 & 29,31 & 68,92 & 7,25 & 32,97 & 43,43 & 61,65 & 55,57 \\
Karang Mati & 11,54 & 30,06 & 4,71 & 2,19 & 22,84 & 24,31 & 10,69 & 18,34 \\
Algae & 0,00 & 0,61 & 0,06 & 12,61 & 1,09 & 0,00 & 0,19 & 3,33 \\
Other Fauna & 6,65 & 2,26 & 2,21 & 1,81 & 12,45 & 8,79 & 6,16 & 17,64 \\
Abiotik & 55,20 & 37,75 & 24,09 & 76,14 & 30,66 & 23,48 & 21,31 & 5,14 \\
\hline \hline
\end{tabular}

Tabel 3. Nilai indeks ekologi karang di masing-masing stasiun.

\begin{tabular}{|c|c|c|c|c|c|c|}
\hline Zonasi & No Stasiun & Nama Pulau/Gosong & Kekayaan genus & $2 \mathbf{H}^{\prime}$ & $\mathbf{E}$ & D \\
\hline \multirow[t]{2}{*}{ Inti } & $\bar{~} 1$ & Gosong Rengat & 22 & 2,77 & 0,66 & 0,07 \\
\hline & 2 & P. Peteloran Timur & 14 & 1,83 & 0,52 & 0,24 \\
\hline \multirow[t]{2}{*}{ Perlindungan } & 3 & Gosong Sebaru & 33 & 3,07 & 0,61 & 0,06 \\
\hline & 4 & P. Jagung & 13 & 2,3 & 0,68 & 0,12 \\
\hline \multirow[t]{2}{*}{ Pemanfaatan } & 5 & P. Jukung & 16 & 2,50 & 0,59 & 0,1 \\
\hline & 6 & P. Sepa Besar & 17 & 1,61 & 0,44 & 0,32 \\
\hline \multirow[t]{2}{*}{ Pemukiman } & 7 & P. Opak Besar & 26 & 3,02 & 0,67 & 0,06 \\
\hline & 8 & P. Panggang & 30 & 2,27 & 0,46 & 0,17 \\
\hline
\end{tabular}

Tabel 4. Parameter lingkungan perairan pada tiap stasiun penelitian.

\begin{tabular}{|c|c|c|c|c|c|c|c|c|}
\hline \multirow{2}{*}{ Parameter } & \multicolumn{8}{|c|}{ Stasiun } \\
\hline & 1 & 2 & 3 & 4 & 5 & 6 & 7 & 8 \\
\hline Suhu $\left({ }^{\circ} \mathrm{C}\right)$ & 28,00 & 28,83 & 31,00 & 29,00 & 28,00 & 29,00 & 29,20 & 29,00 \\
\hline Arus Permukaan m/menit & 3,32 & 4,89 & 13,64 & 13,96 & 28,00 & 9,00 & 5,86 & 17,42 \\
\hline Kecerahan (m) & 8,00 & 8,17 & 9,00 & 9,00 & 6,00 & 10,00 & 8,83 & 7,33 \\
\hline Salinitas & 30,00 & 31,67 & 30,83 & 32,00 & 32,00 & 32,67 & 32,67 & 33,00 \\
\hline $\mathrm{pH}$ & 7,66 & 7,68 & 7,74 & 7,60 & 7,07 & 7,69 & 8,17 & 7,63 \\
\hline
\end{tabular}

Keterangan lokasi : 1 = Gosong Rengat, 2 = Peteloran Timur, 3 = Gosong Sebaru, 4 = Jagung, 5 = Jukung, 6 = Sepa Besar, 7 = Opak Besar, 8 = Panggang

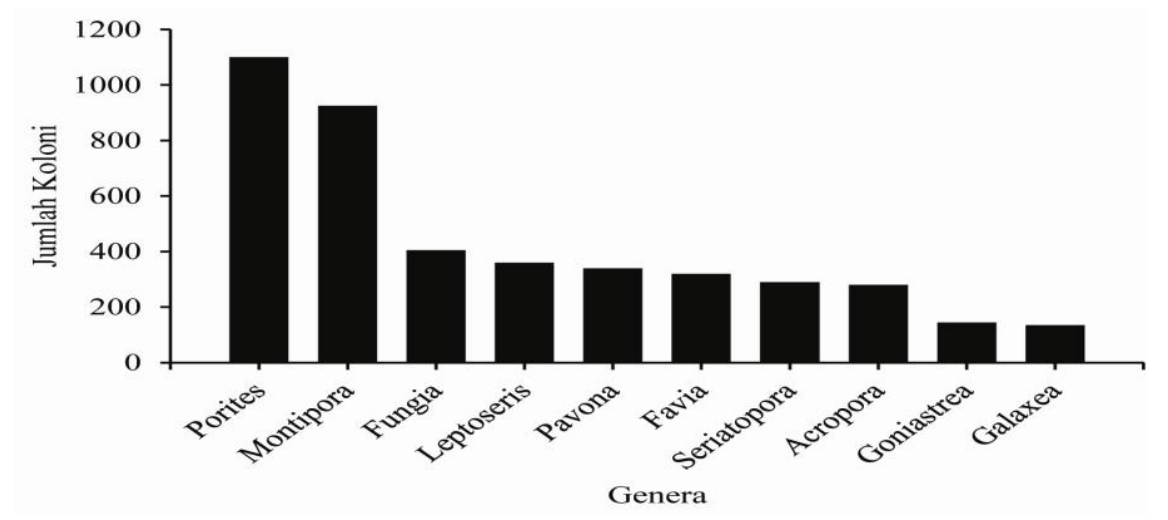

Gambar 3. Sepuluh genera karang dengan kelimpahan tertinggi. 
Secara umum kondisi lingkungan perairan di wilayah Taman Nasional Laut Kepulauan Seribu tergolong baik. Suhu air berkisar $28-31^{\circ} \mathrm{C}$ dengan suhu rata-rata sebesar $29{ }^{\circ} \mathrm{C}$. Kecepatan arus air berkisar 3,32-28 m/menit. Kecepatan arus terendah berada pada stasiun 1 yaitu Gosong Rengat dan yang tertinggi berada pada stasiun 5 yaitu Pulau Jukung. Kecerahan air berkisar 6-10 meter. Kecerahan terendah berada pada stasiun 5 yaitu Pulau Jukung dan yang tertinggi pada stasiun 6 yaitu Pulau Sepa. Salinitas yang teramati berkisar $30-33 \%$ dengan rata-rata $31,86 \%$. Nilai $\mathrm{pH}$ berkisar 7,07-8,17. Nilai pH terendah berada pada stasiun 5 yaitu Pulau Jukung, sedangkan yang tertinggi berada pada stasiun 7 yaitu Pulau Opak Besar.

Persentase tutupan terumbu karang berkisar 7,25-68,93\% yang berarti ekosistem terumbu karang berada pada kondisi buruk hingga baik. Persentase tutupan terendah terdapat di stasiun 4 atau lokasi Pulau Jagung pada zona perlindungan, sedangkan persentase tutupan karang paling tinggi berada pada stasiun 3 yaitu Gosong Sebaru Besar yang juga berada pada zona perlindungan. Rendahnya tutupan terumbu karang di stasiun 4 diduga disebabkan pada beberapa dasawarsa tahun sebelumnya daerah perairannya dijadikan tempat untuk menangkap ikan secara merusak. Pada tahun 1960, kegiatan perikanan yang merusak di Kepulauan Seribu sedang marak terutama penggunaan racun sianida dan pengeboman. Selain itu, kegiatan penambangan terumbu karang untuk membuat pondasi rumah di wilayah Kepulauan Seribu juga menjadi faktor rusaknya terumbu karang di wilayah tersebut. Data tutupan terumbukarang Pulau Jagung pada tahun 2007 sebesar 6,4\% yang merupakan kategori buruk (Estradivari, 2007). Hal ini mengindikasikan bahwa kerusakan dan rendahnya tutupan terumbu karang di Pulau Jagung sudah terjadi lama. Nilai tutupan tertinggi berada di stasiun 3 Gosong Sebaru Besar yang dikarenakan tidak mengalami gangguan oleh wisatawan atau pengunjung dan juga lokasinya berada di antara beberapa pulau sehingga terlindung dari arus yang kencang.

Komposisi karang yang teramati di seluruh stasiun penelitian berjumlah 45 genera dari 16 famili karang. Beberapa genus karang keras yang ditemui dalam jumlah banyak adalah
Porites, Montipora, Fungia, Leptoseris, Pavona, Favia, Seriatopora, Acropora, Goniastrea, dan Galaxea. Kelimpahan tertinggi dijumpai pada genus Porites dengan persentase 19,70\%, dan Montipora dengan persentase 16,69\%. Keberadaan genus Porites dan Montipora yang ditemukan di seluruh stasiun dengan jumlah yang banyak disebabkan oleh beberapa faktor. Mekanisme reproduksi Porites adalah melalui brooding, yaitu kelompok karang dengan telur yang dibuahi di dalam polip, selanjutnya terjadi perkembangan embrio dan larva di dalam polip (Harrison dan Wallace, 1990; Richmond dan Hunter, 1990). Pada genus Porites larva sudah memiliki septa dan alga Zooxanthella yang berkonstribusi menghasilkan energi bagi larva selama proses penempelannya, sehingga larva Porites mampu langsung menempel pada substrat (Richmond, 1997). Selain itu, Porites juga mampu menghasilkan banyak larva planula setiap tahunnya sehingga memiliki tingkat rekrutmen yang cenderung lebih tinggi (Moulding, 2005) dalam Pitasari (2011).

Karang genus Montipora banyak dijumpai dengan bentuk koloni submassive, laminar, encrusting, dan branching (Veron, 1993). Montipora adalah genus yang hampir mirip dengan genus Porites. Pada genus ini, diketahui mekanisme reproduksi seksualnya adalah melalui spawning, yaitu kelompok karang yang memijahkan gametnya (telur dan sperma) ke dalam kolom air, selanjutnya terjadi pembuahan di luar tubuh (polip) (Harrison dan Wallace 1990; Richmond dan Hunter 1990). Montipora dapat menghasilkan banyak sel telur tiap tahunnya (Mate, 1997). Selain itu, genus Montipora ketika larva sudah memiliki alga Zooxanthella yang berkonstribusi memberikan energi selama proses penempelan pada substrat (Richmond, 1997) sehingga hal ini diduga menjadi penyebab Montipora memiliki kelimpahan yang tinggi.

Nilai indeks keanekaragaman karang di tiap-tiap stasiun penelitian berkisar dari 1,61-3,07 yang menandakan bahwa keanekaragamannya tergolong rendah hingga tinggi. Nilai indeks keanekaragaman karang terendah sebesar 1,61 terdapat di stasiun 6, zona pemanfaatan wisata Pulau Sepa Besar, sedangkan nilai indeks keanekaragaman tertinggi berada di zona perlindungan stasiun 3 sebesar 
3,07, Gosong Sebaru Besar. Nilai indeks keanekaragaman karang berdasarkan zonasi pengelolaan Taman nasional Laut Kepulauan Seribu pada zona inti berkisar 1,83-2,77, zona perlindungan berkisar 2,03-3,07, zona pemanfaatan wisata berkisar 2,3-2,5, zona pemukiman berkisar 2,27-3,02. Kuantitas individu dan jenis karang yang ditemukan berpengaruh pada nilai indeks keanekaragaman karang. Lingkungan yang baik, ketersediaan makanan yang cukup, dan adanya tempat berlindung berpengaruh pada populasi karang.

Nilai indeks keseragaman karang di setiap stasiun penelitian berkisar 0,44-0,68 dengan rata-rata sebesar 0,57 . Hal tersebut menandakan bahwa komunitas karang di seluruh stasiun pengamatan tergolong komunitas tertekan hingga komunitas labil. Lokasi yang indeks keseragamannya rendah atau tergolong tertekan dan labil dapat disebabkan oleh dominansi jenis karang tertentu. Nilai indeks dominansi (D) berkisar antara 0,06-0,32 dengan rata-rata sebesar 0,13. Nilai indeks dominansi tersebut tergolong dalam dominasi rendah. Nilai indeks dominansi tertinggi terdapat zona pemanfaatan wisata Pulau Sepa Besar sedangkan dominansi terendah terdapat di zona perlindungan Gosong Sebaru dan zona pemukiman Pulau Opak Besar. Menurut Odum (1998), semakin tinggi nilai dominansi maka akan mempengaruhi kestabilan komunitas dan kemerataan jenis karang.

Secara umum, parameter lingkungan perairan fisik dan kimia di delapan stasiun pengamatan, masih pada batas yang dapat ditoleransi untuk perkembangan terumbu karang. Nilai suhu perairan berkisar antara $28-31^{\circ} \mathrm{C}$. Perbedaan suhu terjadi karena pengambilan data yang dilakukan mulai dari pagi hari hingga menjelang sore. Pada pagi hari suhu cenderung lebih rendah daripada siang atau sore hari. Suhu yang cocok untuk perkembangan terumbu karang berkisar $25-30^{\circ} \mathrm{C}$ sehingga suhu perairan di lokasi pengamatan masih tergolong cocok untuk kehidupan terumbu karang. Suhu berperan sangat penting dalam membatasi sebaran terumbu karang (Nontji, 2005), oleh karena itu, terumbu karang tidak ditemui di daerah bertemperatur tinggi apalagi di daerah dingin, sebaliknya pembuangan air panas ke daerah terumbu karang akan menyebabkan karang menjadi mati.

Arus berfungsi untuk membawa nutrisi dan gas-gas terlarut yang sangat dibutuhkan terumbu karang, serta membersihkan kotorankotoran yang menempel pada karang (Sukarno, 1981). Kecepatan arus pada setiap stasiun pengamatan berkisar antara 3,32-28,00 meter/menit. Pada malam hari diperlukan arus lebih kuat agar supaya dapat membawa oksigen lebih banyak sehingga dapat mencukupi kebutuhan fauna terumbu karang (Verwey, 1929) dalam Soekarno (1981). Ketersediaan oksigen terlarut pada perairan yang agak tertutup seringkali menjadi faktor pembatas pertumbuhan karang batu, sedangkan ketersediaan makanan bisa diperoleh dari hasil fotosintesis alga (Kuenen, 1950) dalam (Soekarno, 1981). Kecepatan arus paling lemah terdapat di Gosong Rengat, sedangkan yang paling kencang berada pada Pulau Sepa Besar.

Kecerahan air berkisar 7,33-10 meter yang merupakan perairan yang visibility tergolong rendah. Kecerahan yang rendah diduga diakibatkan oleh masuknya limbah dari 13 sungai yang bermuara di Teluk Jakarta. Selain itu, limbah tidak hanya didapatkan dari daratan tapi juga tumpahan minyak yang terjadi di tengah laut, terlebih lalu lintas kapal industri di perairan Kepulauan Seribu sangat padat (Estradivari, 2009). Kecerahan berkaitan dengan masuknya cahaya matahari ke dalam perairan hingga mencapai dasar tempat terumbu karang. Intensitas cahaya matahari merupakan faktor yang sangat penting karena karang hermatipik hidupnya bersimbiosis dengan alga Zooxantella yang melakukan proses fotosintesis (Supriharyono, 2000). Hasil fotosintesis tersebut akan diberikan kepada karang sebagai nutrient untuk kebutuhan hidupnya.

Nilai $\mathrm{pH}$ di setiap lokasi pengamatan berkisar 7,08-8,17. Besarnya nilai tersebut tergolong baik untuk kehidupan karang. Nilai $\mathrm{pH}$ yang ideal bagi kehidupan organisame air pada umumnya berkisar 7,0-8,5. Kondisi perairan yang sangat asam maupun sangat basa, akan menyebabkan terjadinya gangguan metabolisme dan respirasi biota karang (Odum, 1994). Nilai pH tertinggi berada di Pulau Opak Besar yang disebabkan adanya Keramba Jaring Apung yang dimanfaatkan oleh warga setempat untuk 
budidaya, sehingga sisa pakan dan sisa metabolisme tercampur di perairan dan mempengaruhi nilai $\mathrm{pH}$. Nilai $\mathrm{pH}$ terendah berada di Pulau Jukung yang berada pada zonasi pemanfaatan wisata.

Data salinitas berkisar antara 30-33\%o, menurut Suharsono (1984), salinitas yang optimal untuk pertumbuhan karang adalah kisaran 30-35\%o, sehingga nilai salinitas di lokasi penelitian sangat baik untuk pertumbuhan dan perkembangan hewan karang.

\section{Simpulan}

Tutupan terumbu karang di zonasi Taman Nasional Laut Kepulauan Seribu DKI Jakarta, berada pada kisaran 7,25-68,93\% atau pada kondisi buruk hingga baik. Jumlah karang yang ditemukan sebanyak 5.523 koloni yang terdiri dari 16 famili dan 45 genera. Karang yang ditemukan dominan adalah genus Porites dan Montipora. Nilai indeks keanekaragaman karang berkisar 1,61-3,07, indeks keseragaman berkisar 0,44-0,68, dan indeks dominansi berkisar 0,06-0,32. Tutupan terumbu karang pada zona pemukiman memiliki kondisi yang baik, yaitu sebesar 55,57-61,65\%. Kondisi fisik kimia lingkungan perairan tergolong baik, sedangkan kecerahan tergolong rendah.

\section{Ucapan Terima Kasih}

Penulis mengucapkan terima kasih kepada tim penilai potensi terumbu karang dari Taman Nasional Laut Kepulauan Seribu yang telah memberikan fasilitas untuk melaksanakan kegiatan penelitian ini.

\section{Daftar Pustaka}

English, S., Wilkinson dan Baker. 1994. Survey Manual for TropicalMarine Resources. Australian Institute of Marine Science, Ownsville, Australia.

Estradivari, Yusri, S., Syahrir, M. dan Timotius, S. 2007. Laporan Terumbu Karang Jakarta: Pengamatan Jangka Panjang Terumbu Karang Kepulauan Seribu (2004-2005). Yayasan Terumbu Karang Indonesia. Jakarta.
Estradivari, Setyawan, E., Yusri, S. dan Syahrir, M. 2009. Terumbu Karang Jakarta : Pengamatan Jangka Panjang Terumbu Karang Kepulauan Seribu (2003-2007). Jakarta, Indonesia. Yayasan Terumbu Karang Indonesia.

Gomez, E.D. dan Yap, H. 1988. Monitoring Reef Condition. Dalam Kenchington, R.A. \& B. Hudson E.T. (Eds.). Coral Reef Management Hand Book. Unesco Regional Office for Science and Technology for South East Asia. Jakarta.

Mate, J.L. 1997. New Reports on the Timing and Mode of Reproduction of Hawaiian Coral. University of Miami. Miami.

Nontji, A. 2005. Laut Nusantara. Cetakan Keempat. Djambatan. Jakarta.

Nybakken, J.W. 1982. Biologi Laut: Suatu Pendekatan Biologis. Editor: M. Eidman, Koesobiono, D.G. Bengen, M. Hutomo dan S. Sukardjo. Gramedia. Jakarta.

Nybakken, J.W. 1992. Biologi Laut: Suatu Pendekatan Ekologis. Gramedia. Jakarta.

Odum, E.P. 1994. Dasar-dasar Ekologi. Edisi Ketiga. Terjemahan oleh Koesbiono, D.G. Bengon, M. Eidmen dan S. Sukarjo. PT. Gramedia. Jakarta.

Pitasari, A., Saptarini, D. dan Aunurohim. 2011. Tingkat Rekrutmen Karang Pada Tiga Tipe Substrat Di Pantai Pasir Putih Situbondo. Institut Teknologi Sepuluh November. Surabaya.

Richmond, R.H. dan Hunter, C.L. 1990. Reproduction and recruitment of corals: comparisons among the Caribbean, the Tropical Pacific, and the Red Sea. Mar. Ecol. Prog. Ser., 60: 185-203.

Sukarno, Hutomo, M., Moosa, M.K. dan Darsono, P. 1982. Terumbu Karang di Indonesia. Lembaga Oseanologi Nasional LIPI. Jakarta.

Sorokin, Y.I. 1993. Coral Reef Ecology. Spinger-Verlag, Berlin, Heidelberg.

Suharsono. 2008. Jenis-jenis Karang di Indonesia. LIPI Pre ss. Jakarta.

Supriharyono, M.S. 2000. Pengelolaan Ekosistem Terumbu Karang. Djambatan. Jakarta.

Veron, J.E.N. 1993. Coral of Australia and The IndoPacific. University of Hawaii Press: Honolulu. 